\title{
Studies on nematode parasites of fishes of Oinam lake Bishnupur district, M anipur, India
}

\section{Sangeeta ${ }^{1}, M$. Shomor endra ${ }^{2}$ and Devashish $\mathrm{K} \mathrm{rr}^{1 *}$}

${ }^{1}$ Division of Wetlands, Fishery Science and Aquaculture Biotechnology, Department of Life Science, Assam (Central) University, Silchar - 788011, INDIA

${ }^{2}$ Fish Disease Research Lab.,Department of Zoology, Thambal Marik College, Oinam -795134 (Manipur), INDIA

*Corresponding author. E mail: devashishKar@yahoo.com

Abstract: An extensive survey was done for fish nematode parasites of few economically important fishes of Oinam Lake, Bishnupur district, Manipur. 9 species of nematodes were encountered. They are Camallanus anabantis, Procamallanus (Procamallanus) saccobranchi, Paraquimperia manipurensis, Paragendria $\mathrm{sp}$., juvenile stages of genus Syphacia, Haplonema, Spinitectus, Philometra and Parascarophis etc. Of these nematode species, Procamallanus (Procamallanus) saccobranchi, Paragendria sp and Haplonema sp. showed maximum abundance (14.28\%) and Paraquimperia manipurensis, Parascarophis sp. showed minimum abundance (4.76\%) of parasites. Among the fish species Anabas testudineus had highest percentage $(50 \%)$ of parasites and Puntius sophore and Colisa labiosus had lowest percentage (1.25\%) of parasites.

Keywords: Nematode parasites, Fishes, Oinam lake, Manipur

\section{INTRODUCTION}

Fish is a vital source of human food particularly in terms of high quality proteins. For the people of Eastern India in general, and North East in particular, fish constitutes a major component of diet. Being a cheap source of animal protein, there is more emphasis on the culture of fishes in recent times. With increasing demand, pisciculture has been a lucrative avocation. But the pisiculturist face many hazards. One among such hazards is the disease resulting from parasitic infections. Manipur has vast potential resources of fisheries in ponds, lakes, rivers and swamps. About $1 / 3^{\text {rd }}$ of the total area of central valley of Manipur is occupied by waterbodies. Fish productivity is adversely affected by parasitic infection and diseases. Fishes harbour a variety of parasites belonging to diverse animal groups. The nematode parasites of a particular water body depend on biotic and abiotic variables and on the presence of intermediate hosts. Their exists relationship between the distribution of nematode and mode of life of their hosts. Fluctuation of nematode infection used to vary during the year and information of such fluctuation has been reported in the case of nematode parasites by a number of seasonal changes of water temperature.

Work of Yamaguti (1958, 1959, 1961, 1962 and 1963) related to occurrence of helminth parasites in vertebrate host is of immense importance. Further Chubb (1979) illustrated the studies of seasonal occurrence of helminths in fresh water fishes in different climate zones of the world. Kar (2007) and Kar and Sen (2007) Studied on systematices list and distribution of fish biodiversity in Mizoram, Tripura and Barak drainage in North East India. Kar et al.(2008) studied on the panorama of fish diversity in certain rivers, wetlands and protected areas in Assam. Kar and Barbhuiya (2009) studied on the Mahseer fishes of Barak Drainage, Mizoram and Tripura. Barbhuiya et al. (2009) worked on fish biodiversity in certain rivers of Tripura. Shomorendra and Jha (2003) reported on a new nematode parasite Paraquimperia manipurensis n.sp. from the intestine of Anabas testudineus. The present study deals with a systematic summary and abundance of nematode parasites from Oinam Lake, Manipur.

\section{MATERIALS AND METHODS}

Study area: Oinam Lake is a shallow and very old semiterrestrial freshwater lake having an area of about $0.71 \mathrm{~km}^{2}$. It is situated at Oinam village in the Bishnupur district of Manipur and is located at about $21 \mathrm{~km}$ on the SouthWestern side of Imphal city. It is located in the intersection of $24^{\circ} 25^{\prime}-24^{\circ} 40^{\prime} \mathrm{N}$ latitude and $93^{\circ} 45^{\prime}-93^{\circ} 55^{\prime}$ longitude and is located about $783 \mathrm{~m}$ MSL. It has a maximum depth of $0.82 \mathrm{~m}$. It contains about 35 species of fishes belonging to major families like Notopteridae, Cyprinidae, Bagridae, Siluridae, Channidae and Anabantidae.

Collection of fish: The fishes were collected alive almost every alternate day from the Oinam Lake and brought to the laboratory in the polythene bags containing water of 


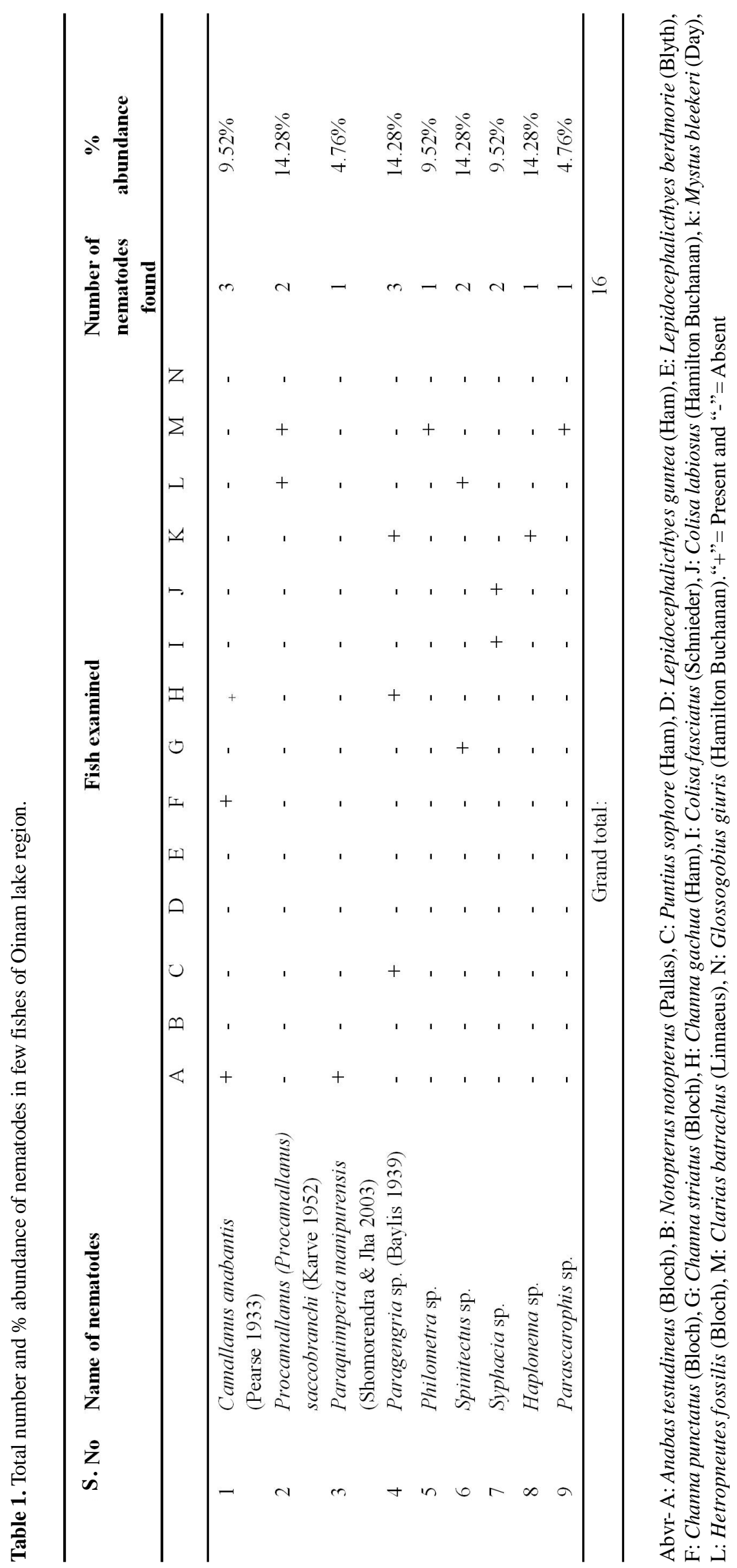


Table 2. Number of the fishes infected and the \% abundance of nematode infection in the Oinam Lake region..

\begin{tabular}{|c|c|c|c|c|c|}
\hline S.No. & Name of fish & $\begin{array}{l}\text { No. of fish } \\
\text { examined }\end{array}$ & $\begin{array}{l}\text { No. of fish } \\
\text { infected (a) }\end{array}$ & Name of nematodes & \% abundance \\
\hline$\overline{1}$ & Anabas testudineus (Bloch) & 94 & 40 & $\begin{array}{c}\text { Camallanus anabantis } \\
\text { Paraquimperia manipurensis }\end{array}$ & $50 \%$ \\
\hline 2 & Notopterus notopterus (Pallas) & 15 & - & - & - \\
\hline 3 & Puntius sophore (Ham) & 20 & 1 & Paragendria sp. & $1.25 \%$ \\
\hline 4 & Lepidocephalicthyes guntea (Ham) & 15 & - & - & \\
\hline 5 & Lepidocephalicthyes berdmorie (Blyth) & 15 & - & - & \\
\hline 6 & Channa punctatus (Bloch) & 21 & 5 & Camallanus anabantis & $6.25 \%$ \\
\hline 7 & Channa striatus (Bloch) & 50 & 3 & Spinitectus sp. & $3.75 \%$ \\
\hline 8 & Channa gachua (Ham) & 8 & 4 & $\begin{array}{l}\text { Camallanus anabantis } \\
\text { Paragendria sp. }\end{array}$ & $5 \%$ \\
\hline 9 & Colisa fasciatus (Schnieder) & 34 & 2 & Syphacia sp. & $2.5 \%$ \\
\hline 10 & Colisa labiosus (Hamilton Buchanan) & 5 & 1 & Syphacia sp. & $1.25 \%$ \\
\hline 11 & M ystus bleekeri (Day) & 45 & 8 & $\begin{array}{l}\text { Paragengria sp. } \\
\text { Haplonema sp. }\end{array}$ & $10 \%$ \\
\hline 12 & Hetropneutes fossilis (Bloch) & 20 & 6 & $\begin{array}{c}\text { Procamallanus } \\
\text { (Procamallanus)saccobranchi, } \\
\text { Spinitectus sp. }\end{array}$ & $7.5 \%$ \\
\hline 13 & Clarias batrachus (Linnaeus) & 20 & 10 & $\begin{array}{c}\text { Procamallanus } \\
\text { (Procamallanus)saccobranchi, } \\
\text { Philometra sp. } \\
\text { Parascarophis sp. }\end{array}$ & $12.5 \%$ \\
\hline 14 & $\begin{array}{l}\text { Glossogobius giuris } \\
\text { (Hamilton Buchanan) }\end{array}$ & 20 & - & - & - \\
\hline
\end{tabular}

the same locality. Small fishes were killed by pithing and somewhat larger specimens by blow on the top of cranium. The external body surface as well as the internal body eg. alimentary canal, liver, heart, kidney, gonads, swim bladder etc were thoroughly examined for the occurrence of parasites. The living worms were placed directly in warm $70 \%$ alcohol for fixation. An alternate methods was used for killing and stretching by immersing the worms for 0.5-1 minutes in glacial acetic acid (Berland 1961), then preserved in $70 \%$ alcohol. Further the nematodes were cleared in Lactophenol and mounted in glycerine gelly.

\section{RESULTS AND DISCUSSION}

The parasites collected from 14 species of fish hosts examined belonged to 9 diverse groups viz: $C$. anabantis, P. (Procamallanus) saccobranchi, P. manipurensis, Paragendra sp., juvenile stages of genus Syphacia, Haplonema, Spinitectus, Philometra and Parascarophis etc. Table. 1 shows the total number and \% abundance of nematodes in few fishes of Oinam Lake region. Among these species C. anabantis (Pearse, 1933) had 9.52\%, P. (Procamallanus) saccobranchi has $14.28 \%$, P. manipurensis (Shomorendra and Jha, 2003) had 4.76\%, Paragendria sp. (Baylis ,1939) had 14.28\%, Philometra sp. had 9.52\%, Spinitectus sp. had $14.28 \%$, Syphacia sp. had $9.52 \%$, Haplonema sp. had $14.28 \%$ and Parascarophis sp. had $4.76 \%$. Of these species $P$. (Procamallanus) saccobranchi, Paragendria sp. and Haplonema sp. had highest percentage of parasites and Paragendria and Parascarophis had lowest percentage of parasites.

Table 2 shows the number of the fishes infected and the $\%$ abundance of nematode infection in the Oinam Lake region. The percentage of infection in $A$. testudineus (Bloch) had 50\%, P. sophore (Ham) has 1.25\%, Channa punctatus (Bloch) has $6.25 \%$, C. striatus (Bloch) has $3.75 \%$, C . gachua (Ham) had 5\%, C. labiosus (Hamilton Buchanan) has $1.25 \%$, M. bleekeri (Day) has $10 \%, \mathrm{H}$. fossilis (Bloch) has $7.5 \%, \mathrm{C}$. batrachus (Linnaeus) has $12.5 \%$. Thus, A. testudineus was found to have the highest percentage of parasites $(50 \%)$, while had lowest percentages of infection P. sophore $(1.25 \%)$ and C. labiosus (1.25\%).

\section{ACKNOW LEDGEMENTS}

The authors are thankful to the Director, ZSI, Kolkata; authorities of Assam University and Thambal Marik College, Oinam for giving laboratory facilities. Thanks are due to Shri S. R. Dey Sarkar of ZSI, identifying the 
specimens and to UGC, New Delhi for granting a major research project to the second author.

\section{REFERENCES}

Barbuiya, A. H., Das, B., Darlong, L., Tarafdar, R. G., Sharma, R., Sharma, S. S., Datta, S., Das, B., Barman, R., Deb, S., Saha, B. , Kar, D. (2009). Fish Biodiversity in certain rivers of Tripura, Environment \& E cology, 27 (1): 222-227.

Chubb, J.C.(1979). Seasonal occurrence of helminth freshwater fishes, part-1, Monogenia. Advances in Parasitology, 15; 133-199.

Jha, A. N. (1989). Characteristics of the parasite fauna of the fishes of Sikandarpur reservoir as the Muzaffarpur in the North Bihar Ph. D. Thesis Bihar Univ. Muzaffarpur, Bihar. Kar, D. (2003). Fishes of Barak drainage, Mizoram and Tripura pp 203-211. In: Environment, pollution and Management (Eds) Kumar, A; Bohra, C and Singh, L.K. APH Publishing Corporation (New Delhi) . ppxii+604.

Kar, D. (2007). Fundamentals of Limnology and Aquaculture Biotechnology, Daya Publishing House (New Delhi) pp xiv+609.

Kar, D. and Sen, N. (2007). Systematice list and distribution of fish biodiversity in Mizoram, Tripura and Barak drainage in North -East India. Zoos' Print J ournal, 22 (3) : 25992607.
Kar, D. and Barbuiya, A. H. (2009). Mahseer fishes of Barak Drainage, Mizoram and Tripura, Souvenier: National Symposium on Cold water Fisheries Management: New Strategies and Approaches, 2-4 Oct 09, Directorate of Cold, water Fisheries Research (ICAR), Bhimtal-Uttarakhand, India: pp. 77-80.

Shomorendra, M. and Jha, A. N. (2003). On a new nematode parasite Paraquimperia manipurensis n. sp. from the intestine of Anabas testudineus (Bloch). Uttar Pradesh. J.Zool., 23 (2): 155-157.

Yamaguti, S. (1958). Systema Helminthum Vol. I. The digenetic trematodes of vertebrates, Interscience, New York. Druzno lake Part- I, Acta Parasite Pole., 6:1-64.

Yamaguti, S. (1959). Systema Helminthum Vol. II. The digenetic trematodes of vertebrates, Interscience, New York. Druzno lake- Part- I, Acta Parasite Pole., 6:1-64.

Yamaguti, S. (1961). Systema Helminthum Vol-III. The Nematode vertebrates Part I and II Interscience Publisher, pp. I-1261.

Yamaguti, S. (1962). Systema Helminthum Vol. III. The nematodes of vertebrates, invertebrates, Inter- Science, New York.

Yamaguti, S. (1963). Systema Helminthum Vol. V. Acanthocephala, Inter- Science, New York. 